\title{
The Implementation of Filial Play in Improving Parent-Child Attachment Relationships during Study from Home
}

\author{
$1^{\text {st }}$ Sri Milfayetty ${ }^{1}, 2^{\text {nd }}$ Rahmulyani ${ }^{2}, 3^{\text {rd }}$ Shofia Mawaddah $^{3}$ \\ \{milfayetty@unimed.ac.id ${ }^{1}$,rahmulyani@unimed.ac.id ${ }^{2}$, Shofia.mawaddah@unimed.ac.id ${ }^{3}$ \} \\ Faculty of Education Universitas Negeri Medan ${ }^{1,2,3}$
}

\begin{abstract}
This study will examine the role of filial play in enhancing parent-child attachment ties. This study employed a qualitative methodology and FGD to collect data. 3 out of 15 FGD participants were identified as Filial Coaching Mentoring (FCM) participants. These participants were chosen based on their parents' talents and commitments, as well as their child's strengths and shortcomings as assessed by SDQ. The data were analyzed qualitatively thematically. Analysis of 40 FCM play sessions with parents and 24 observation sessions revealed an improvement in parents' capacity to structure activities, listen empathically, play child-centered imaginary games, and set boundaries. The results showed that parents could ensure their children's attachment while learning at home. It has also improved children's self-confidence, perseverance, and interest in studying. Thus, filial play is excellent for enhancing parent-child attachment bonds when studying at home.
\end{abstract}

Keywords. Filial play, parent-child attachment, qualitative thematically.

\section{Introduction}

During the Covid-19 outbreak, the Indonesian government through the Ministry of Education and Culture required all schools to carry out studying from home activities through online, offline or in combination of the two. This is done to reduce the risk of the spread of Corona virus, especially in children. This policy is stipulated through Circular Letter of The Minister of Education No. 36962/MPK. A/HK/2020 which applies studying from home activities from April 2020 until now.

With the enactment of this studying from home policy, the teaching role that is usually done by the education unit, has now been transferred to the family unit. During studying from home, the home becomes a learning center for all family members. However, the current conditions show that the studying from home did not fully go well. There are many obstacles faced by parents as the main partners of children in carrying out studying from home activities.

Based on the results of a survey conducted by Tanoto Foundation related to studying from home activities at 332 principals, 1,368 teachers, 2,218 students and 1,712 parents, it was concluded that there are three main problems faced by parents. First, as many as $56 \%$ of parents who have children in elementary school and $34 \%$ of parents who have children in junior high school claim to be less patient and feel saturated in handling the ability and concentration of children while studying from home. Second, as many as $19 \%$ of parents with children in elementary school and $28 \%$ of parents with children in junior high school report 
that they have difficulty explaining the lesson material to the children. Third, as many as $15 \%$ of parents who have children in the elementary school and $24 \%$ of parents who have children in the junior high school find it difficult to understand their children's subject matter.

This is in line with the results of Wardani and Ayriza research (2020) which states that some obstacles faced by parents when accompanying children to study from home include difficulty in fostering children's interest in learning, difficulty understanding lesson materials, not having enough time to accompany the child because they have to work, being impatient in accompanying children to learn, difficulty in operating gadgets, and other constraints related to the access of internet services.

In September 2020, an interview to parents at SMP Swasta X in Medan about studying from home showed the need for parents to be able to control the situation by improving their ability in building the secure attachment with their children. In studying from home, parents hold important roles and become the children's main partners in going through their daily learning process to be meaningful. Thus, it becomes important for parents to be able to build strong emotional relationships with children. According to Papalia (2010) the emotional relationship between the children and their caregiver in the long term is called attachment. Ainsworth (in Eliasa, 2011) adds that attachment is a strong emotional connection gained through the interaction of the children with their caregiver who is usually a parent.

The term attachment was first used by John Bowlby (1907 - 1990) [1] who stated that a lack of maternal affection can cause anxiety, anger, behavioral deviations, and depression in children. In line with this, Papalia (2010) added that attachment is an active and affective reciprocal relationship between two individuals and is characterized by interaction as an effort to maintain its closeness.

The quality of the children relationship with their parents or caregivers determines the quality of their internal working model regarding themself and others which will be the assessment mechanism of environmental acceptance [1] in Pramana 1996). Children who feel accepted by their environment will develop a secure attachment with their attachment figure. Children with secure attachment will also develop trust in mother and their environment. Ainsworth in [2] also added that secure attachment in the first year of a child's life is essential for later psychological development. Some studies have concluded that children with secure attachment are better able to foster healthy, more harmonious, responsive and do not dominate friendship relationships (Parke and Waters in Parker, et al., 1995). In addition, other studies have also found that children who have a secure attachment are better in handling difficult tasks and do not give up quickly.

Attachment has a significant impact on children development. Dewi (2013) stated that attachment between parents and children plays an important role in building self-reliance for children in performing their tasks and responsibilities. In addition, Manalu and Maherni (2019) also stated that children who have a secure attachment with parents usually show a better learning motivation. Therefore, it can be concluded that by building a secure attachment with children, parents can foster their children's motivation in learning and understand the obstacles faced by their children during learning from home (BDR) activities.

One of many strategies that parents can do in building attachment with children is to implement filial play. Filial play is a technique in creative art that designed to help parents build close and supportive relationships with children. The results of a study by [3] showed that play therapy or creative play therapy positively affects the development of positive relationships between parents and children. The results of this play therapy are very effective if done on a non-directive basis.

Therefore, this study aims to apply filial play to parents so that parents are able to build attachment with children through non-directive play methods. In addition, parents can also 
help solve children's learning problems while learning from home (BDR) and can accompany children to learn more effectively.

Playtime is very important for children because play is a natural way for children to communicate. For children, games are words and play is their language. Adults usually voice their experiences, thoughts and feelings with words. While children use the game to explore and express what they think and feel. During playtime, parents can build different patterns of relationships with their children. Thus, children can feel empowered, important, understood, and accepted as they are.

Taylor \& Francis (2006) explained that filial play is a technique aimed at strengthening the relationship between parents and children by using play time for $10-30$ minutes for once a week. In filial play, parents are directed to perform a structured playtime with their child for 10-30 minutes using the toys they choose together. Through filial play parents are directed to provide an empathy response to children feelings, help children to build their self-esteem, to form children self-control and responsibility, and to set a healthy boundaries during playtime. The basic principles of playing in filial play are:

a. Parents provide 10-30 minutes to play with children. Children are free to decide how to spend their playtime. Parents follow the way their children play by showing interest and observing their children without giving direction or questions. During the designated time parents actively participate especially when requested by their children.

b. The main task for parents is to show empathy to their children by trying to understand the feelings, thoughts and expressions of their children during playtime. Parents try to see and experience the game by putting themselves in children's shoes. Therefore the role of the parents is merely accompanying the children.

c. The parents then communicate it with the child by: a) verbally explaining what children do, b) verbally reflecting what children say, c) verbally reflecting the feelings that children actively show during playtime.

Parents must be clear and consistent with the playing time provided for the child. This is done to give children a sense of responsibility for their attitude and behaviour as well as to help them to have a good self-control.

The mentoring process is done by applying the relationship in filial play adapted from "Seven Layers of Mentoring Dialogue" by Megginson and Clutterbuck in APAC filial play module (2008) which are building social relationships, implementing games without direction, dealing with various problems, context, insights about selfjoints, behavioral change and integrative (self-engagement). These seven are the patterns that a mentor needs to train to parents who participate in filial play mentoring program.

The patterns were later adapted by Milfa [5] from The Seven Eyed Model Supervision depicted by Peter Howkins and Robin Shohet [6]. Its implementation in mentoring is explained below:

a. Focus on children and the way they show themselves. Help parents pay attention to their children and then connect it with different aspects of children life.

b. Exploring strategies and interventions carried out by parents. Why and when parents do interventions and what other alternative strategies and consequences therefore they can develop their knowledge and expertise in doing the intervention.

c. Exploring children's relationship with parents. Increase the capacity and the efficiency of responses in relationships between parents and children.

d. Focus on parents. How parents complement themselves and more effectively respond to children. 
e. Focus on parent relationships. Parent-child relationships are a major concern in this regard. Thus, the dynamics of relationships that occur unconsciously can be understood.

f. Focus on the mentoring process. Feelings, thoughts and imagination.

This is then applied into 8 mentoring sessions that are done once a week. Therefore, it can produce positive changes to parents' ability, especially in building emotional attachment with their children.

\section{Method}

This research is an applied study that aims to find out the implementation of filial play in improving the parent-child attachment relationships during study from home. The research method used is qualitative research using focus group discussion (FGD) and filial play mentoring sessions. Filial play is a method of play that provides a good interaction between parents and children to improve the quality of attachment between the two.

A total of 3 participants from 15 participants who took part in the FGD were designated as Filial Coaching Mentoring (FCM) participants. These participants were determined based on the FCM eligibility requirements which are the parents' abilities and commitments, as well as children's strengths and weaknesses that were measured by SDQ.

The instruments used in the intervention are filial play guidelines consisting of implementation guidelines and modules of filial play materials. The mentoring of filial play begins with a written contract agreed with the parents. This contract consists of eight filial play sessions consisting of creative play with certain conditions. Filial play is a joint process based on mutual trust, openness and professionalism to improve quality, develop skills, provide reflections on improving quality and ensure the safety of filial play sessions run by mentors with parents. All conversations in the process of filial play are confidential. Then, parents set the schedule of filial play with their children.

The mentoring process conducted in playing filial is done through the following 8 stages:

\subsection{The First Session}

Discussing how to do special time, set a safe room and process, create a session sheet, make a diary about the session that is run with the child. In addition, discussing how to send a report before the implementation of filial play, carry out mentoring and diary writing. Mentor also explaining how to observe children, set a boundary, do a special time and reflex process to children.

\subsection{The Second Session}

Checking in with life balance. In this session the mentor discussing about: a) Physical condition that needs to be improved. b) Spiritual aspects associated with parental duties, and c) Emotional aspects that control feelings in order to stay calm when facing difficult situations.

\subsection{The Third Session}

Parents were asked to tell about the process of playing with their children. In this section the mentor would remind the parents about the border. Then discuss U-shape techniques in 
behavioural changes, matching energy while playing, and doing creative visualization and storytelling.

\subsection{The Fourth Session}

Parents were asked to discuss about the play activities that have been done with the children and to tell about the changes that have happened to the children.

\subsection{The Fifth Session}

Discussing the preparation of celebrations and creating emojis to find out what children think of filial play sessions that have been done. Then, the mentor discussed the development of selfconcept in children and the perception of parents about themselves. Self-concept can be described like mirroring, thus if children could reflect on the acceptance and appreciation of parents during filial play then children can build new values for themselves.

\subsection{The Sixth Session}

Discussing attachment and how to build relationships. In addition, the mentor also explained about boundary and optimization of children's dreams. Mentor also discussed the 8 traps in decision making, namely: anchoring trap, status quo, sunk-cost trap, confirmingevidence trap, framing trap, overconfidence trap, prudence trap, and recall ability trap.

\subsection{The Seventh Session}

Discussing movement, embodiment, projection and role play. The development of the play can also be used as a way to build attachments with children.

\subsection{The Eighth Session}

Discussing about self-care. This can be done by setting the time for sleep, the time for physical exercise, the time to focus, the time for self-reflection, the time to rest and the time to play and the time to connect. In addition, it also discussed how to build a growth mind set or look at everything with a growing mindset.

\section{Result and Discussion}

Study on the implementation of filial play in improving parent-child attachment relationships during study from home shows.

\subsection{Strengths and Difficulties Questionnaire (SDQ)}

The findings of Strengths and Difficulties Questionnaire (SDQ) before and after the investigation revealed:

Based on this evidence, it is known that the average grade of children's SDQ fall into the normal group when considering the child's level of difficulty in terms of emotional symptoms, behavioral problems, hyperactivity, social problems, and prosocial behaviors. 
Table 1. Strengths and Difficulties Questionnaire (SDQ).

\begin{tabular}{lllllll}
\hline Children's Difficulties & \multicolumn{2}{c}{ Child 1 } & \multicolumn{2}{c}{ Child 2 } & \multicolumn{2}{c}{ Child 3 } \\
\cline { 2 - 6 } & Pra & Post & Pra & Post & Pra & Post \\
\hline Emotional Symptoms & Normal & Normal & Normal & Normal & Normal & Normal \\
Behavior Issues & Borderline & Normal & Normal & Normal & Normal & Normal \\
Hyperactivity & Borderline & Normal & Borderline & Normal & Normal & Normal \\
Social Problems & Normal & Normal & Borderline & Normal & Borderline & Normal \\
Prosocial behavior & Normal & Normal & Borderline & Normal & Normal & Normal \\
\hline
\end{tabular}

\subsection{Attachment Styles Questionnaire}

Table 2. Attachment Styles Questionnaire.

\begin{tabular}{cll}
\hline Responden & Pra & Post \\
\hline Child 1 & insecure & secure \\
Child 2 & insecure & secure \\
Child 3 & insecure & secure \\
\hline
\end{tabular}

This data reveals that the study's findings after implementing filial play to average respondents revealed that the attachment relationship between parents and children was secure.

\subsection{Filial Play Skill.}

Table 3. Filial Play Skills

\begin{tabular}{cccccccc}
\hline \multirow{2}{*}{ Responden } & \multicolumn{3}{c}{ Child 1 } & & Child 2 & & Child 3 \\
\cline { 2 - 7 } & Pra & Post & Pra & Post & Pra & Post \\
Structuring & Less & Good & Less & Good & Less & Good \\
Empathic listening & Fair & Good & Fair & Good & Fair & Good \\
Child centered imaginary play & Less & Good & Fair & Good & Less & Good \\
Limit setting & Less & Good & Less & Good & Less & Good \\
& & & & & & \\
\hline
\end{tabular}

According to the findings in table 3, respondents' filial play skills improved following the intervention.

According to the findings of this study, filial play skills help parents to understand the rules of play. Parents can also offer their complete attention to their child's behavior and feelings during play sessions, as well as respond verbally to the child's behavior and feelings. 
Parents could also engage in play with their children, using facial expressions, tone, and adding drama in their games, and always following the child's preferences. Parents might make rules for their children's play sessions in order to keep them safe. Parents can communicate play restrictions clearly and specifically using firm yet non-punitive sound intonation.

[6] outline skills that enable parents to express affection genuinely and effectively. In the end, this condition encourages parents to strengthen their bond with their children in daily situations. A previously insecure attachment has been upgraded to secure one. Parents may build relationships with their children that are safe, joyful, and powerful [1] in Pramana 1996; Papalia, 2010). This secure attachment allows parents to accompany and encourage their children to learn at home (Manalu and Maherni, 2019; [3]. The improvement of the parent-child attachment relationship, in particular, has been shown to benefit in the control of children's development, particularly in handling emotional disorders, behavioral problems, hyperactivity, social problems, and prosocial behaviors. This can be seen in the shift from abnormal to normal test results.

\section{Conclusion}

The implementation of filial play in conjunction with filial coaching and mentoring activities allows parents to manage their time together with their children on a regular, consistent, and effective basis. Parents get the ability to structure activities (structuring), listen empathically (empathic listening), play imaginary games centered on their children (child center imaginative play), and set boundaries (limit setting). During study from home, this situation helps parents to form a secure relationship to their children. It has also aided children in being more self-reliant and far less easily discouraged, as well as improving their learning interests. As a result, filial play is considered useful in increasing parental attachment to children during study from home.

\section{References}

[1] Wardani A, dini YA. Analisis kendala orang tua dalam mendampingi anak belajar di rumah pada masa pandemi Covid-19. Obsesi: jurnal Pendidikan anak usia 2020; 5: $772-782$.

[2] Papalia D, Old S, Feldman R. Human Development (Psikologi Perkembangan): Bag I s/d IV.

[3] Kembang EE. Pentingnya kelekatan orangtua dalam internal working model untuk pembentukan karakter anak (kajian berdasarkan teori kelekatan dari john bowlby). Karakter sebagai Saripati Tumbuh.

[4] Pramana W. The utility of theories of parenting, attachment, stress, and stigma in predicting adjustment to illness. 1996.

[5] Santrock J. Life-span development. 
[6] Parker JG, Rubin KH, Price JM, et al. Child Development and Adjustment : A developmental Psychology Perspective. Developmental Psychopatology Volume 2.

[7] Dewi A, Udayana TV-JP, 2013 undefined. Hubungan kelekatan orangtua-remaja dengan kemandirian pada remaja di smkn 1 denpasar. ojs.unud.ac.id 2013; 1: 181-189.

[8] Manalu P, Marheni A. Hubungan antara kelekatan orangtua-remaja dengan motivasi belajar pada remaja di SMA Negeri 4 Denpasar. Jurnal Psikologi 2019; 6: 130-138.

[9] Milfayetty S. Innovation in Teaching and Learning Through Creative Art Model. European Journal of Social Science Education, https://books.euser.org/files/books/edu/Recent_Ideas_and_Developments_in_Educatio n.pdf\#page=126 (2017, accessed September 13, 2021).

[10] Wittenborn A, Faber A. Emotionally focused family therapy and play therapy techniques. Taylor \& Francis 2006; 34: 333-342.

[11] Bratton S, Landreth G. Child-parent relationship therapy (CPRT) treatment manual: An evidence-based 10-session filial therapy model. 2019.

[12] Coaching PH-2009). TCH of, 2009 undefined. Coaching supervision. books.google.com.

[13] Milfayetty S. Case study in supervision. APAC.

[14] Topham G, VanFleet R. Filial therapy: A structured and straightforward approach to including young children in family therapy. Australian and New Zealand Journal. 